Endocrinol. Japon. 1988, 35 (5), 763-768

\title{
NOTE
}

\section{Effect of Prolonged ACTH Stimulation on Adrenal Renin and Aldosterone}

\author{
Yolchi IZUMI*, Masanobu HONDA, Noboru FUKUDA \\ AND Michinobu HATANO
}

The second Department of Internal Medicine, Nihon University School of

Medicine, 30 Ooyaguchi Kamimachi, Itabashi-ku, Tokyo 173, Japan

\begin{abstract}
Changes in adrenal renin, which have been regarded as mediator of aldosterone secretion in the adrenal gland, following prolonged ACTH treatment were investigated in male Wistar rats. After 2 days of daily sc injection of ACTH (Cortrosyn-Zinc, $50 \mu \mathrm{g} /$ day), parallel increases in adrenal renin and aldosterone, and plasma aldosterone (PA) were induced. The plasma renin activity (PRA) was slightly but not significantly decreased. Prolonged treatment with ACTH for 8 days increased the adrenal renin, causing a marked reduction in the adrenal aldosterone concentration. The degree of decrease in the PRA was again not significant and similar to that after 2 days of ACTH treatment. Contrary to previout reports which have indicated participation of adrenal renin in the regulation of aldosterone secretion in the adrenal gland, the present results showed reciprocal changes in adrenal renin and aldosterone after prolonged treatment with ACTH. The present findings suggest a complicated relation between adrenal renin and aldosterone secretion in the adrenal gland.
\end{abstract}

It is well established that prolonged ACTH treatment, which initially increases aldosterone secretion, causes the plasma aldosterone concentration to fall to basal values or below $(1,8,13,17)$. Such an effect of ACTH has been observed in both human subjects and animals. In patients with Cushing disease due to excess ACTH production, aldosterone secretion is normal or low. Several studies have demostrated a suppressed renin-angiotensin system fol-

Received March 24, 1988

*To whom request: for reprints should be addressed. lowing a few days treatment with ACTH, leading to the suggestion that the impeded function of the renin-angiotensin system resulting from sodium retention during prolonged ACTH treatment might mediate the decline in aldosterone secretion $(2,20)$. Other investigators have reported low plasma aldosterone values after long-term treatment with ACTH in spite of a sustained high level of PRA $(17,19)$.

Reduction of the amount of several biosynthetic enzymes in the adrenal glomerulosa zone by prolonged ACTH treatment has been reported (1). The 11-hydroxylase ac- 
tivity and 18-hydroxylase activity were decreased, suggesting that prolonged ACTH treatment affects the late pathway in the inhibition of aldosterone biosynthesis.

It has been widely accepted that a reninlike enzyme in the adrenal gland participates in the regulation of aldosterone secretion $(3,5,15,16)$. Additional studies have revealed the existence of adrenal angiotensin I, II, III and an angiotenin converting enzyme $(6,11,14)$, indicating the possibillity of full components of the renin-angiotensin system being present in the adrenal gland. The present experiments were undertaken to determine the changes in adrenal renin in the inhibitory action of prolonged ACTH treatment on aldosterone.

\section{Materials and Methods}

Male Wistar rats weighing $200-240 \mathrm{~g}$ received sc injections of ACTH (Cortrosin-Zinc, Daiichi Pharmaceutical Co., Tokyo) at dose of $50 \mu \mathrm{g}$ daily for 8 days (prolonged ACTH stimulation). Control animals were injected with $0.1 \mathrm{ml}$ of saline during the same period. In short-term ACTH stimulating experiments, rats were injected with ACTH or saline as the control for 2 days. All the animals were killed by decapitation on the final day of each series of injections. Blood samples were collected from the neck vessels into tubes containing $5 \mathrm{mg}$ of EDTA for measure- ment of the plasma renin activity (PRA) and plasma aldosterone (PA). The adrenal glands were removed after being flushed free of blood with $0.9 \%$ saline via the aorta. Capsules of the removed adrenal glands (mainly the zona glomerulosa) were separated and homogenized in $1 \mathrm{ml}$ of $0.1 \mathrm{M}$ Tris acetate buffer, $\mathrm{pH} 7.4$, at $4^{\circ} \mathrm{C}$, and centrifuged at $1800 \mathrm{~g}$ for $20 \mathrm{~min}$ at $4^{\circ} \mathrm{C}$. The supernatant was collected for determination of the adrenal renin activity and aldosterone concentration. The adrenal renin activity was measured in Tris acetate buffer, $\mathrm{pH}$ 7.4, using nephrectomized rat plasma as substrate following the method described previously (4). To estimate the adrenal renin activity and PRA, the generated angiotensin I was measured with a CEA-IRE-SORIN kit (France). PA was separated on a Sephadex LH-20 column and then measured by radicimmunoassay with a CEA-IRE-SORIN kit. The adrenal aldosterone in the supernatant was measured directly with the same kit. The protein concentration of the supernatant was determined by the method of Lowry et al., (9). The results were expressed as the mean \pm SE. Statistical analysis was performed by Student's $t$-test for unpaired variables. $P$ values of less than 0.05 were considered statistically significant.

\section{Results}

Eigure 1 shows the effects of short and prolonged treatment with ACTH on the adrenal renin. The short-term treatment for

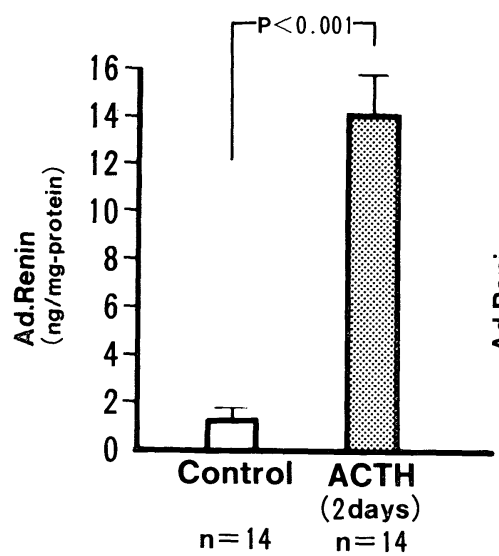

$n=14$

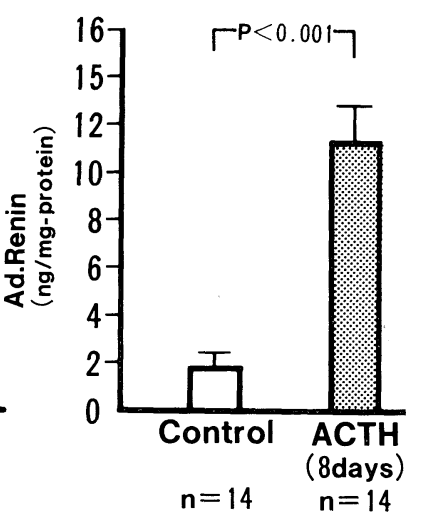

Fig. 1. Effects of short ( 2 days) and prolonged (8 days) treatment with ACTH on adrenal renin (Ad. Renin). Each bar represents the mean \pm SE. 
2 days significantly increased the adrenal renin concentration to $14.5 \pm 1.3 \mathrm{ng} / \mathrm{mg}$ protein/h from a control value of $1.1 \pm 0.1$. Similarly to the short-term treatment, the prolonged treatment with ACTH for 8 days increased the adrenal renin to $11.1 \pm 1.6 \mathrm{ng} /$ $\mathrm{mg}$-protein/h from a control value of $1.9 \pm$ 0.4. As shown in Fig. 2, the short-term treatment with ACTH induced a significant increase in the adrenal aldosterone concentration from $11.5 \pm 1.9 \mathrm{ng} / \mathrm{mg}$-protein as the control value to $19.7 \pm 1.3$. In contrast to the short treatment, the prolonged treatment decreased the adrenal aldosterone concen- tration to $3.9 \pm 0.7 \mathrm{ng} / \mathrm{mg}$-protein from a control value of $15.8 \pm 1.2$ Fig. 3 shows the changes in PA. An increase in PA, from $103.8 \pm 19.3 \mathrm{ng} / \mathrm{dl}$ as the control value to $249.1 \pm 22.3$, after the short treatment with ACTH was observed. However, there was no significant difference between the PA values for the control and prolonged ACTH treatment $(70.8 \pm 8.5 \mathrm{ng} / \mathrm{mg}$-protein as the control value and $57.1 \pm 3.8$ as the values after ACTH treatment for 8 days). The changes in PRA are summarized in Fig. 4. The short-term treatment let to a slight but not significant desrease in PRA to 8.7
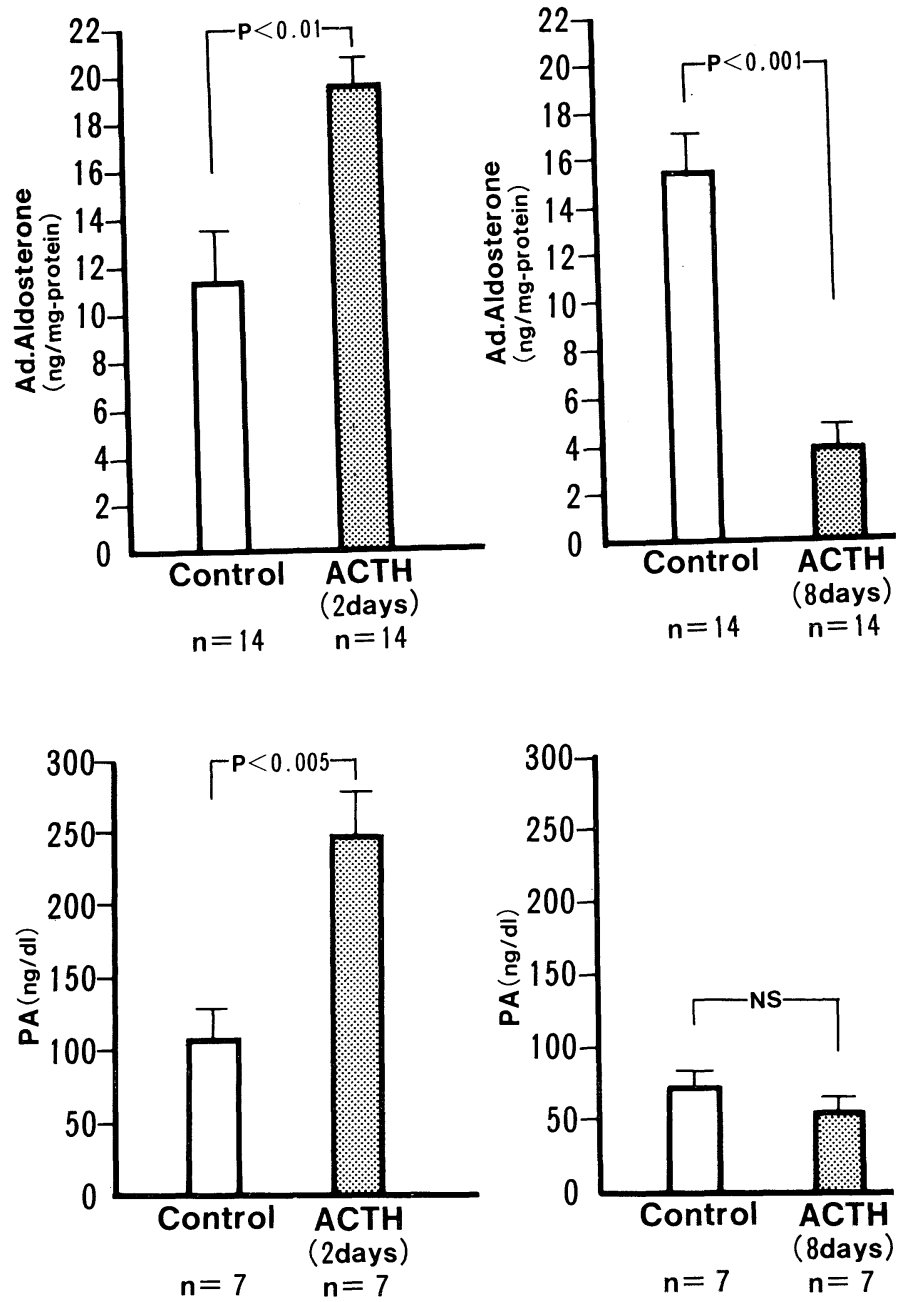

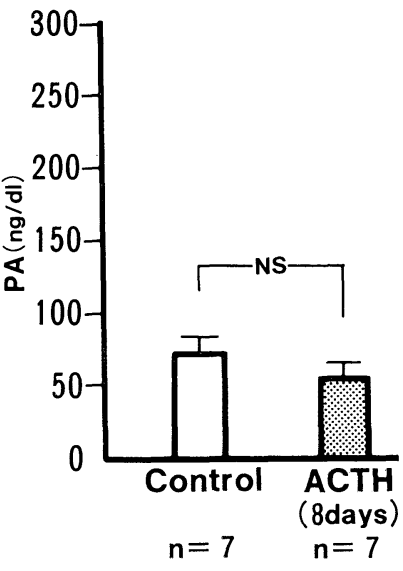

Fig. 2. Effects of short (2 days) and prolonged (8 days) treatment with ACTH on adrenal aldosterone (Ad. Aldosterone). Each bar repesents the mean \pm SE.
Fig. 3. Effects of short ( 2 days) and prolonged (8 days) treatment with ACTH on plasma aldosterone (PA). Each bar represents the mean \pm SE. 

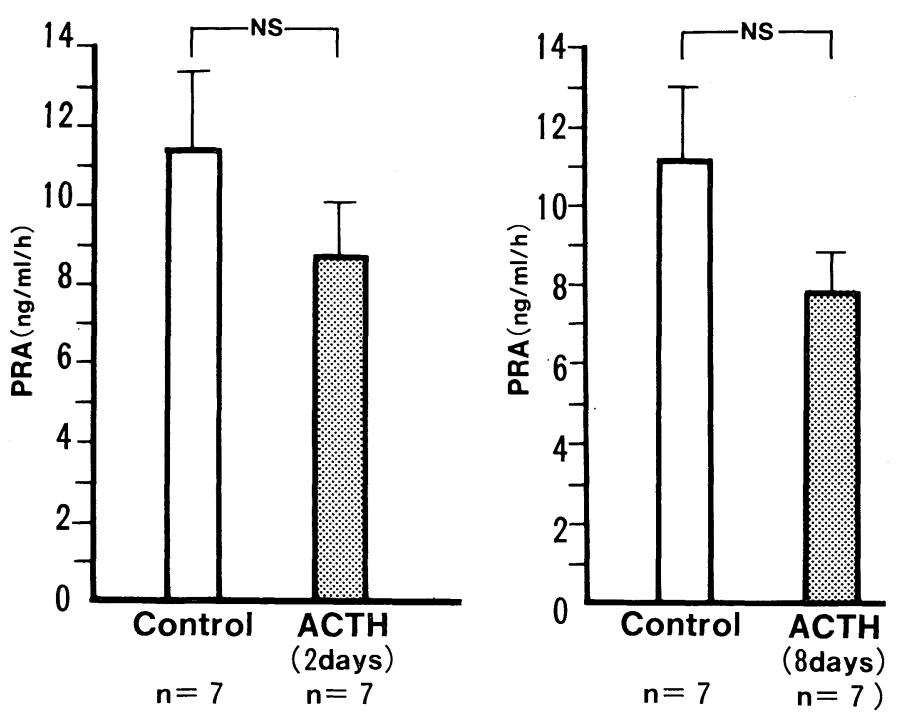

Fig. 4. Effects of short ( 2 days) and prolonged (8 days) treatment with ACTH on PRA. Each bar represents the mean \pm SE.

$\pm 1.4 \mathrm{ng} / \mathrm{ml} / \mathrm{h}$ from a control value of 11.4 1.8. Similarly to the changes in PRA after short-term ACTH treatment, the prolonged ACTH treatment induced a slight but not significant decrease in PRA, from $11.3 \pm 1.7 \mathrm{ng} / \mathrm{ml} / \mathrm{h}$ as the control value to $7.8 \pm 1.0$.

\section{Discussion}

The present experiments confirm the results of previous studies in which prolonged ACTH treatment returned the PA to basal levels or below while short-term ACTH treatment stimulated aldosterone release $(1$, $8,13,17)$. Several mechanisms have been proposed to explain such biphasic aldosterone responses to prolonged ACTH stimulation, involving an initial elevation followed by diminished release. Reduction of PRA resulting from sodium retention caused by prolonged treatment with ACTH was considered to suppress aldosterone release (2, 20). However, the present data which demonstrate similar changes in PRA, i.e. slight but not significant decreases, following both short- and long-term ACTH stim- ulation, which induced opposing changes in PA or adrenal renin, do not indicate such a mechanism.

Attempts have been made to explain the chronic effect of ACTH on aldosterone based on changes in metabolic clearance rate $(12,22)$. However, the marked reduction of the adrenal aldosterone concentration in the present study suggests primary suppression of aldosterone production in the adrenal gland. The effect of prolonged ACTH treatment on aldosterone release seems therefore to be attributable to the inhibition of aldosterone biosynthesis. Several reports have demonstrated no response of aldosterone after prolonged ACTH treatment to exogenous angiotensin II $(1,7)$. Morphological changes in the glomerulosa zone were observed, and were considered to be a cause of the attenuation of aldosterone release $(10,18)$. Morphological changes in the glomerulosa zone could lead to a poor response of aldosterone release to angiotensin II or ACTH. However, a high response of adrenal renin still remained after prolonged ACTH treatment.

Since the presence of a renin-like enzyme was identified in the adrenal gland (21), 
many studies on this enzyme have been undertaken. The parallel changes in adrenal renin and adrenal aldosterone observed after short-term ACTH treatment are consistent with previous reports which support the importance of adrenal renin in the regulation of aldosterone release. In contrast, prolonged ACTH treatment caused reciprocal changes in the adrenal renin and aldosterone concentration.

Ganten et al. (5) described a significant reduction of $\mathrm{PA}$ in the absence of change in adrenal renin in rats bearing a transplanted ectopic anterior pituitary tumor for 52 days. Although they suggested a close relation between adrenal renin and aldosterone release, their results question the role of adrenal renin in the control of aldosterone release. Our data seem to emphasize their findings.

While the site of action of the adrenal renin-angiotensin system remains unclear, it is possible that prolonged ACTH treatment could exert its influence after the site where the adrenal renin-angiotensin system acts in the aldosterone biosynthetic pathway. Aguilera et al. (1) reported decreases in angiotensin II receptors in adrenal glomerulosa cells during prolonged ACTH treatment. If adrenal renin reflects adrenal angiotensin II, it can be supposed that receptors of angiotensin II in the adrenal glomerulosa cells were also decreased by prolonged ACTH treatment. A diminished action of adrenal angiotensin II might stimulate adrenal renin release as well as an interaction between renal renin and circulating angiotensin II. Another possibility is that even if both adrenal renin and angiotensin II are increased after prolonged ACTH treatment, these substanses cannot finally stimulate aldosterone biosynthesis. The response of aldosterone secretion to ACTH in adrenal glomerulosa cells from rats treated by prolonged ACTH administration was reduced in the absence of a fall in the cyclic AMP response to the peptide (1).
The unaffected response of cyclic AMP to ACTH in such glomerulosa cells from rats treated by prolonged ACTH administration could explain the high levels of adrenal renin after prolonged ACTH treatment in the present experiments, implicating cyclic AMP as an apparently important mediator for renin release in the kidney.

The lack of parallel changes in adrenal renin and aldosterone following prolonged ACTH treatment would support a complex role for adrenal renin in the regulation of aldosterone release. Although prolonged ACTH treatment stimulates adrenal renin, probably as a consequence of increased cyclic AMP, the treatment did not affect any other pathway. Aguilera et al. (1) reported suppressed 11-hydroxylase and 18-hydroxylase activities in adrenal glomerulosa cells from rats treated by prolonged ACTH administration. Oelkers (19) also demonstrated decreased aldosterone accompanied by reduced 18-OH-corticosterone. These results prove that prolonged ACTH treatment caused lesions of the late enzyme activities in the adrenal zona glomerulosa. The adrenal renin or renin-angiotensin system may thus act at an early step in the aldosterone biosynthesis pathway. Also prolonged ACTH treatment might suppress the stimulatory action of the adrenal reninangiotensin system on aldosterone release. However, it is necessary to elucidate details of changes in adrenal angiotensin II in further studies.

\section{References}

1) Aguilera, G., K. Fujita and K. Catt (1981). Mechanism of inhibition of aldosterone of aldosterone secretion by adrenocorticotropin. Endocrinology 108, 522-528.

2) Benraad, T. J. and P. W. C. Kloppenborg (1970). Plasma renin activity and aldosterone secretory rate in man during chronic ACTH administration. J. Clin. Endocrinol. Metab. 31, 581-583. 
3) Doi, Y., K. Atarashi, R. Franco-Saenz and P. J. Mulrow (1984). Adrenal renin : a possible regulator of aldosterone. Clin. Exp. Hypertension $[A]$ 5, 1119-1126.

4) Doi, Y., K. Atarashi, R. Franco-Saenz and P. J. Mulrow (1984). Effect of changes in sodium or potassium balance, and nephrectomy, on adrenal renin and aldosterone concentrations. Hypertension 6 (Suppl I), I-124-129.

5) Ganten, D., U. Ganten, S. Kubo, P. Granger, W. Nowaczynski, R. Boucher and J. Genest (1974). Influence of sodium, potassium and pituitary hormones on iso-renin in rat adrenal glands. Am. J. Physiol. 227, 224-229.

6) Ganten, D., K. Hermann, Th. Unger and R. E. Lang (1983). The tissue renin-angiotensin systems : focus on brain angiotensin, adrenal gland and arterial wall. Clin. Exp. Hypertension. $[A]$ 5, 1099-1118.

7) Kraiem, Z., T. Rosenthal, T. Rotzak and B. Lunenfeld (1979). Angiotensin II and K challenge following prolonged ACTH administration to normal subjects. Acta Endocrinol. 91, 657-665.

8) Liddle, G. W., L. E. Duncan and F. C. Bartter (1956). Dual mechanism regulating adrenocortical function in man. Am. J. Med. $21,380-386$.

9) Lowry, O. H., N. J. Rosebrough, A. L. Farr and R. J. Randall (1951). Protein measurement with the folin phenol reagent. $J$. Biol. Chem. 193, 265-275.

10) McDougall, J. G., A. Butkus, J. P. Coghlan, D. A. Denton, J. Muller, C. J. Oddie, R. M. Robinson and B. A. Scoggins (1980). Biosynthetic and morphological evidence for inhibition of aldosterone production following administration of ACTH to sheep. Acta Endocrinol. 94, 559-570.

11) Mendelsohn, F. A. O. (1984). Localization of angiotensin converting enzyme in rat forebrain and other tissue by in vitro autoradiography using ${ }^{125} \mathrm{I}$-labelled MK351A. Clin. Exp. Pharmacol. Physiol. 11, 431-435.

12) Messerli, F. H., W. Nowaczynski, M. Honda, J. Genest and O. Kuchel (1976). Effect of ACTH on steroid metabolism. J. Clin.
Endocrinol. Metab. 42, 1074-1080.

13) Muller, A. F., A. M. Riondel and E. L. Manning (1956). Effect of corticotropin on secretion of aldosterone. Lancet 2, 1021-1023.

14) Nakamura, M., K. S. Misono, M. Naruse, R. J. Workman and T. Inagami (1985). A role for the adrenal renin-angiotensin system in the regulation of potassium-stimulated aldosterone production. Endocrinology 117 (5), 1772-1778.

15) Naruse, M. and T. Inagami (1982). Markedly elevated specific renin levels in the adrenal in genetically hypertensive rats. Proc. Natl. Acad. Sci. USA 79, 3295-3299.

16) Naruse, M., C. R. Sussaman, K. Naruse, R. V. Jackson and T. Inagami (1983). Renin exists in human adrenal tissue. J. Clin. Endocrinol. Metab. 57, 482-487.

17) Newton, M. A. and J. H. Laragh (1968). Effect of corticotropin on aldosterone excretion and plasma renin in normal subject, in essential hypertension and in primary aldosteronism. J. Clin. Endocrinol. Metab. 28, 10061013.

18) Nussdorfer, G. G., G. Neri, A. S. Belloni, G. Mazzocchi, P. Rebuffat and G. Robba (1982). Effect of ACTH on the zona glomerulosa of sodium-loaded timolol malesttreated rat: stereology and plasma hormone concentration. Acta Endocrinol. 99, 256-262.

19) Oelkers, W. (1985). Prolonged ACTH infusion suppresses aldosterone secretion in spite of high renin activity. Acta Endocrinol. 108, 91-97.

20) Rauh, W., L. S. Levine, K. Gottesdiener and M. New (1978). Mineralocorticoid, salt balance and blood pressure after prolonged ACTH administration in juvenile hypertension. Klin. Wochenschr. 56 Suppl I, 161-167.

21) Ryan, J. W. (1967). Renin-like enzyme in the adrenal gland. Science 158, 1589-1590.

22) Zipser, R. D., P. F. Speckart, P. K. Zia, W. A. Edmiston, F. Y. K. Lau and R. Horton (1976). The effect of ACTH and cortisol on aldosterone and cortisol clearance and distribution in plasma and whole blood. J. Clin. Endocrinol. Metab. 43, 1101-1109. 